\title{
Effect of Secondary Treated Distillery Spentwash on Physiological and Quality Parameters of Bt Cotton-II
}

\author{
Shyoram $^{1}$, S.S. Angadi ${ }^{1}$, Deepak Kumar Yadav $^{2}$, B.S. Patil ${ }^{2}$ and Siddharth Tripathi ${ }^{2}$ \\ ${ }^{1}$ University of Agricultural Sciences, Dharwad 580005 India \\ ${ }^{2}$ Ministry of Agriculture \& Farmers Welfare, New Delhi, India \\ *Corresponding author
}

\section{A B S T R A C T}

\begin{tabular}{|l|}
\hline Ke y w o r d s \\
Distillery \\
spentwash, Bt \\
cotton, Quality \\
parameters, \\
Physiological \\
parameters
\end{tabular}

\section{Introduction}

Distilleries, one of the most important agrobased industries in India, produce ethanol and other organic solvents from molasses for commercial and industrial uses. They generate large volumes of foul smelling coloured waste water known as spentwash. Approximately 40 billion litres of spentwash is generated per annum from 285 distilleries in the country. Spentwash is purely plant origin and contains large quantities of soluble organic constituents and plant nutrients. It does not contain any toxic elements or compounds. The only problem with distillery effluent is excess Biological Oxygen Demand (BOD), Chemical Oxygen Demand (COD) and soluble salt content.

Being a rich source of nutrients especially potassium, spentwash use is advantageous especially in black soil (vertisols), which require much higher $\mathrm{K}$ levels to meet plant needs. Vertisols rich in clay minerals require more $\mathrm{K}$ before it is made available to the crops. Since the conventional methods of waste treatment are uneconomical and especially the difficulty in handling and 
transporting of large quantities, hence an alternative methods like application of distillery effluents to agricultural land is receiving increasing attention. The increasing cost of fertilizer of most essential nutrients also demand the attention. In this context the trial was conducted to make the best use of spentwash in cotton.

\section{Materials and Methods}

Field experiment was carried out during kharif 2010 to at the Main Agricultural Research Station (MARS), University of Agricultural Sciences, Dharwad. The distillery spentwash used in the present experiment was collected from Sri Lakashmi Narayana Distillery Unit, Garag located near MARS, UAS, Dharwad. Analysis of spentwash (Table 1) as indicated in paper entitled "Performance of Bt Cotton to Secondary Treated Distillery Spentwash in Northern Transitional Zone of Karnataka-I" et al., The Madras Agricultural Journal. The experiment was laid out in RCBD design with the nine treatments replicated thrice.

Spentwash was applied on the basis of nitrogen requirement of $\mathrm{Bt}$ cotton and the deficiency, if any, of $\mathrm{P}_{2} \mathrm{O}_{5}$ was met through single superphosphate. 40 per cent of spentwash was applied 15 days before sowing of Bt cotton. Remaining 60 per cent was applied in three splits-equally (15 DAS, 30 DAS and 60 DAS).

Experimental soil had $\mathrm{pH}$ of 7.63, EC of 0.20 $\mathrm{dS} \mathrm{m}^{-1}$ organic carbon content of 0.47 per cent and 203.70, 35.23, 395.50 kg ha-1 of available $\mathrm{N}$ (alkaline $\mathrm{KMnO}_{4}$ ), $\mathrm{P}_{2} \mathrm{O}_{5}$ (Olsen's $\mathrm{P}$ ) and $\mathrm{K}_{2} \mathrm{O}$ ( $\mathrm{NH}_{4} \mathrm{OAc}$ ). CGR (Crop Growth Rate), RGR (Relative Growth Rate) and NAR (Net Assimilation Rate), were analysed between 61 and 90 days after sowing as suggested by Watson (1952), Radford (1967) and Watson (1952), CGR, RGR and NAR, respectively.
The cultural practices were followed as recommended. The seeds of Bunny BG-II Bt cotton were sown with a common spacing of $90 \mathrm{~cm} \times 60 \mathrm{~cm}$. The quality characteristics of fibre were assessed at Central Institute for Research on Cotton Technology (CIRCOT) regional centre, Dharwad by using a high volume instrument (HVI model statex Fibrotex).

\section{Results and Discussion}

\section{Effect on physiological parameters}

Significantly higher leaf area $\left(51.3 \mathrm{dm}^{2}\right.$ pant $\left.^{-1}\right)$ and LAI (0.95) were obtained with the application of $1.5 \mathrm{~N}$ through spentwash than the rest of the treatments at all the growth stages, but it was on par with application of 1 $\mathrm{N}$ through distillery spentwash $\left(44.7 \mathrm{dm}^{2}\right.$ pant $^{-1}$ leaf area and $\left.0.83 \mathrm{LAI}\right)$. The response can be noticed with enhanced nucleic acid synthesis, cell division, reduction in the abscission of leaves, energy availability (ATP), expansion of cells, which in turn helped in leaf expansion resulted in higher leaf area as well as LAI. These results are in agreement with the findings of Bhukia et al., (2009). Total dry matter production and supply of required photosynthates for the developing bolls largely depends on leaf area and leaf area index (LAI). The photosynthetic efficiency of crop plants as measured by net assimilation rate is dependent upon photosynthetic capacity as expressed by LAI (Watson, 1952). Under field conditions, an increase in LAI may therefore improve the yield, provided that such an increase was commensurate with an increased rate of dry matter production in reproductive parts. Leaf area over unit ground area gives a fairly good idea of photosynthetic surface. Growth indices like CGR (4.580 to $6.070 \mathrm{~g} \mathrm{~m}^{-2}$ day $^{-1}$ ), NAR (0.0243 to $\left.0.0269 \mathrm{~g} \mathrm{dm}^{-2} \mathrm{day}^{-1}\right)$ and RGR $\left(0.0205\right.$ to $0.0218 \mathrm{~g}^{-1}$ day $\left.^{-1}\right)$ differed significantly with application of nutrients 
through spentwash than application of nutrients through straight fertilizers (CGR ranged from 3.862 to $4.250 \mathrm{~g} \mathrm{~m}^{-2} \mathrm{day}^{-1}$, NAR ranged from 0.0240 to $0.0248 \mathrm{~g} \mathrm{dm}^{-2} \mathrm{day}^{-1}$ and RGR ranged from 0.0205 to $0.0207 \mathrm{~g}^{-1} \mathrm{day}^{-1}$ ) and control $\left(2.886 \mathrm{~g} \mathrm{~m}^{-2}\right.$ day $^{-1}, 0.0225 \mathrm{~g} \mathrm{dm}^{-2}$ day $^{-1}$ and $0.0200 \mathrm{~g}^{-1} \mathrm{day}^{-1}$, CGR, NAR and RGR, respectively). This may be attributed to greater accumulation of photosynthates with growth advancement. These results are in agreement with the findings of Shivanand (2001). The RGR in cotton is more closely associated with vegetative growth than seed cotton yield (Coy, 1976). The growth and physiological attributes have shown significant response to spentwash application and in turn cotton yield.

The total dry matter production (339.7 $\mathrm{g}$ plant $\left.^{-1}\right)$ and yield (2566.1 $\left.\mathrm{kg} \mathrm{ha}^{-1}\right)$ were significantly higher with application of $1.5 \mathrm{~N}$ through spentwash than the rest of the treatments, but was on par with T6, T7, T1. Yield was higher in these treatments because of the retention of more bolls and diversion of higher proportion of photo-assimilates to reproductive parts. This might be due to higher production of assimilates and better partitioning of photo-assimilates and increased metabolic activity and resulted in increased total dry matter production and the present findings are similar to the findings of Suganya and Rajannan (2009). Application of $1.5 \mathrm{~N}$ through spentwash retained more number of good bolls per plant (31.2) due to reduction in abscission of square and boll. This might be due to micronutrient and growth regulators which completely checked the abscission promoting effect of ABA and thus reduced the shedding of square and boll over the control and RDF alone. It was suggested that endogenous auxin content may play a key role in phenomena of abscission and a certain concentration might regulate the process (Verma, 1978). However, it was on par with T6, T7, T1. Whereas, harvest index did not differ significantly with application of spentwash and chemical fertilizers. However it was higher with all levels of spentwash and ranged from 32.2 to 34.7 per cent than chemical fertilizer treatments (30.2 to $32.5 \%$ ).

\section{Quality parameters}

Quality parameters of Bt cotton did not differ significantly with application of spentwash and fertilizers except micronaire value. This might be due to genetic makeup of plant rather than nutrient composition (Aruna and Reddy, 2009). Significantly lower micronaire value (3.73) was noticed with the application of 0.25 $\mathrm{N}$ through spentwash $+0.75 \mathrm{~N}$ through fertilizers and recommended package of practices as compared to other treatments. However, it was on par with application of 1.5 $\mathrm{N}$ through spentwash, $0.75 \mathrm{~N}$ through spentwash $+0.25 \mathrm{~N}$ through fertilizers, $0.5 \mathrm{~N}$ through spentwash $+0.5 \mathrm{~N}$ through fertilizers, $1 \mathrm{~N}$ through spentwash (3.87) and control (3.97). This might be because of the presence of growth regulators in spentwash, which have influenced fibre initiation and development. Fineness of fibre is associated with wall thickness of fibre which requires indole -3acetic acid and gibberellic acid and boron are necessary to maintain fibre elongation (Thind, 2007) (Table 2).

Spentwash supplies IAA, gibberellic acid and micronutrients reported by Murugaragavan and Mahimairaja (2010). Whereas, application of fertilizers recorded higher micronaire value (4.07 to 4.13) than any of the doses. This might be due to deficiency of IAA, gibberillic and micronutrient. Boron deficiency symptoms were probably related to reduced activity in the pyrimidine biosynthetic pathway which might have reduced synthesis of UDP-glucose and UDP-sugar involved in cell wall composition of fibre (Thind, 2007). Hence, micronaire values were higher with application of fertilizers. 
Table.1 Physiological and yield parameters of Bt cotton as influenced by application of distillery spentwash

\begin{tabular}{|c|c|c|c|c|c|c|c|c|c|c|}
\hline Treatment & $\begin{array}{c}\text { CGR } \\
\left(\mathrm{g} \mathrm{m}^{-2} \mathrm{day}^{-}\right. \\
\left.{ }^{-}\right) \\
61-90 \\
\text { DAS }\end{array}$ & $\begin{array}{l}\text { NAR } \\
\left(\mathrm{g} \mathrm{dm}^{-2}\right. \\
\left.\text { day }^{-1}\right) \\
61-90 \\
\text { DAS }\end{array}$ & $\begin{array}{c}\text { RGR } \\
\left(\mathrm{g} \mathrm{g}^{-1}\right. \\
\left.\text { day }^{-1}\right) \\
61-90 \\
\text { DAS }\end{array}$ & $\begin{array}{l}\text { Total } \\
\text { dry } \\
\text { matter } \\
\text { plant }{ }^{-1} \\
(\mathrm{~g})\end{array}$ & $\begin{array}{l}\text { Leaf area } \\
\text { plant }^{-1} \\
\left(\mathrm{dm}^{2}\right)\end{array}$ & LAI & $\begin{array}{l}\text { Bad } \\
\text { opened } \\
\text { Bolls } \\
\text { plant }^{-1}\end{array}$ & $\begin{array}{l}\text { Good } \\
\text { opened } \\
\text { bolls } \\
\text { plant }^{-1}\end{array}$ & $\begin{array}{c}\text { Kapas } \\
\text { Yield } \\
\left(\mathrm{kg} \mathrm{ha}^{-1}\right)\end{array}$ & $\begin{array}{l}\mathrm{HI} \\
(\%)\end{array}$ \\
\hline T1- $1 \mathrm{~N}$ through spentwash & 5.633 & 0.0268 & 0.0214 & 304.0 & 44.7 & 0.83 & 9.09 & 28.8 & 2436.7 & 32.6 \\
\hline T2- $1.5 \mathrm{~N}$ through spentwash & 6.070 & 0.0260 & 0.0210 & 339.7 & 51.3 & 0.95 & 9.10 & 31.2 & 2566.1 & 32.2 \\
\hline T3- $1 \mathrm{~N}$ through fertilizers & 3.862 & 0.0240 & 0.0205 & 221.3 & 33.0 & 0.61 & 9.85 & 18.8 & 1930.3 & 32.5 \\
\hline T4- $1.5 \mathrm{~N}$ through fertilizers & 4.250 & 0.0248 & 0.0207 & 243.3 & 39.3 & 0.73 & 10.18 & 21.9 & 2075.7 & 30.2 \\
\hline $\begin{array}{l}\text { T5 - } 0.25 \mathrm{~N} \text { through spentwash } \\
+0.75 \mathrm{~N} \text { through fertilizers }\end{array}$ & 4.580 & 0.0243 & 0.0205 & 287.0 & 42.3 & 0.78 & 9.24 & 25.9 & 2392.5 & 33.9 \\
\hline $\begin{array}{l}\text { T6 - } 0.5 \mathrm{~N} \text { through spentwash } \\
+0.5 \mathrm{~N} \text { through fertilizers }\end{array}$ & 6.019 & 0.0269 & 0.0218 & 327.3 & 48.0 & 0.89 & 9.17 & 30.9 & 2545.9 & 34.7 \\
\hline $\begin{array}{l}\text { T7 - } 0.75 \mathrm{~N} \text { through spentwash } \\
+0.25 \mathrm{~N} \text { through fertilizers }\end{array}$ & 5.664 & 0.0259 & 0.0212 & 309.7 & 48.0 & 0.89 & 9.11 & 28.3 & 2469.4 & 32.6 \\
\hline T8- RPP (RDF + FYM) & 4.115 & 0.0248 & 0.0203 & 241.3 & 38.6 & 0.72 & 9.19 & 20.9 & 2048.2 & 31.4 \\
\hline $\begin{array}{l}\text { T9- Control (no spentwash and } \\
\text { no fertilizers) }\end{array}$ & 2.886 & 0.0225 & 0.0200 & 121.7 & 23.2 & 0.43 & 7.50 & 14.2 & 1359.0 & 33.1 \\
\hline S.Em \pm & 0.137 & 0.0008 & 0.0003 & 14.8 & 2.5 & 0.05 & 0.54 & 1.5 & 110.5 & 2.1 \\
\hline $\mathrm{CD}(\mathrm{P}=0.05)$ & 0.410 & 0.0024 & 0.0009 & 44.4 & 7.4 & 0.14 & NS & 4.4 & 331.3 & NS \\
\hline
\end{tabular}

Note: RPP- Recommended package of practices

HI- Harvest Index 
Table.2 Quality parameters of Bt cotton as influenced by application of spentwash and fertilizers

\begin{tabular}{|c|c|c|c|c|c|c|c|c|}
\hline Treatment & $\begin{array}{l}\text { Seed } \\
\text { Index }\end{array}$ & $\begin{array}{l}\text { Lint } \\
\text { Index }\end{array}$ & $\begin{array}{l}\text { GOT } \\
(\%)\end{array}$ & $\begin{array}{c}2.5 \% \\
\text { SL } \\
(\mathrm{MM})\end{array}$ & $\begin{array}{l}\text { Uniformity } \\
\text { ratio }(\%)\end{array}$ & $\begin{array}{l}\text { Micronaire } \\
\text { value }\end{array}$ & $\begin{array}{l}\text { Tenacity } \\
\qquad(\mathrm{g} / \mathrm{t})\end{array}$ & $\begin{array}{l}\text { Elongation } \\
\quad(\%)\end{array}$ \\
\hline T1- $1 \mathrm{~N}$ through spentwash & 10.03 & 4.98 & 33.13 & 32.90 & 45.00 & 3.87 & 22.93 & 5.70 \\
\hline T2- $1.5 \mathrm{~N}$ through spentwash & 10.17 & 5.05 & 33.20 & 33.57 & 44.33 & 3.77 & 22.50 & 5.63 \\
\hline T3- 1 N through fertilizers & 10.32 & 5.07 & 32.93 & 33.07 & 44.33 & 4.07 & 22.60 & 5.53 \\
\hline T4- $1.5 \mathrm{~N}$ through fertilizers & 10.55 & 5.01 & 32.20 & 33.37 & 44.33 & 4.13 & 22.53 & 5.53 \\
\hline $\begin{array}{r}\text { T5 - } 0.25 \mathrm{~N} \text { through spentwash } \\
+0.75 \mathrm{~N} \text { through fertilizers }\end{array}$ & 9.77 & 4.86 & 33.20 & 33.17 & 44.67 & 3.73 & 23.40 & 5.77 \\
\hline $\begin{array}{c}\text { T6 - } 0.5 \mathrm{~N} \text { through spentwash }+ \\
0.5 \mathrm{~N} \text { through fertilizers }\end{array}$ & 9.85 & 5.03 & 33.80 & 33.27 & 44.00 & 3.83 & 22.87 & 5.73 \\
\hline $\begin{array}{r}\text { T7 - } 0.75 \mathrm{~N} \text { through spentwash } \\
+0.25 \mathrm{~N} \text { through fertilizers }\end{array}$ & 9.92 & 4.92 & 33.20 & 33.70 & 44.00 & 3.80 & 22.47 & 5.67 \\
\hline T8- RPP (RDF + FYM) & 9.64 & 4.83 & 33.40 & 33.90 & 44.33 & 3.73 & 23.40 & 5.63 \\
\hline $\begin{array}{l}\text { T9- Control (no spentwash and } \\
\text { no fertilizers) }\end{array}$ & 9.03 & 4.85 & 34.93 & 32.13 & 45.33 & 3.97 & 23.43 & 5.57 \\
\hline S.Em \pm & 0.28 & 0.15 & 0.50 & 0.35 & 0.65 & 0.09 & 0.38 & 0.06 \\
\hline $\mathrm{CD}(\mathrm{P}=0.05)$ & NS & NS & NS & NS & NS & 0.26 & NS & NS \\
\hline
\end{tabular}

Note: GOT - Ginning Out Turn

RPP- Recommended package of practices

SL- Span Length 
The use of distillery spentwash not only increased the crop yield but also improved physiological and fibre quality parameters than application of chemical fertilizers alone. It has substituted for 100 per cent of N, 36 per cent of $\mathrm{P}_{2} \mathrm{O}_{5}$ and 100 per cent of $\mathrm{K}_{2} \mathrm{O}$ in $\mathrm{Bt}$ cotton. Thus, tapping the bio-energy potential of distillery effluent could augment and sustain the Bt cotton yield.

\section{References}

Aruna, E. and Reddy, S., 2009, Response of Bt cotton to plant geometry and nutrient combinations, Indian. J. Agric. Res., 43(3): 206-210.

Bhukia, T. D., Patil, S. G. and Angadi, S. S., 2009, Crop nutrition through distillery spentwash in maize (Zea mays L.). $J$. Environ. Sci. Engg., 51(2): 87-92.

Coy, A. C., 1976, Growth analysis of diverse upland cotton in varied dissertation. Australian Intl. Bull., 37: 544.

Murugaragavan, R. and Mahimairaja, S, 2010, Charaterization of distillery spentwash for its valuable nutrient substitute to dryland agriculture. $J$. Ecobiol. 24 (2): 169-174

Radford, P. T., 1967, Growth analysis formulae, their use and abuse. Crop Sci., 8: 171-175.

Shivanand, V. B., 2001, Influence of distillery effluent on growth and physiology of sunflower (Helianthus annuus). M. Sc. (Agri.) Thesis, University of Agricultural Sciences, Dharwad (India).

Suganya, K. and Rajannan, G., 2009, Effect of one time post-sown and pre-sown applications of distillery spentwash on the growth and yield of maize crop. Botany Res. Internl., 2(4): 288-294.

Thind, S. K., 2007, Advances in cotton physiology. Satish serial publication house, Delhi. pp. 239-277.

Verma, S. K., 1978, Interaction between kinetin and ABA in controlling abscission of flower bud and bolls of cotton (G. hirsutum). Acta Botany India, 6: 52-57.

Watson, D.J., 1952, The physiological basis of variation in yield. Annals of Botany, 4: 101-105.

\section{How to cite this article:}

Shyoram, S.S. Angadi, Deepak Kumar Yadav, B.S. Patil and Siddharth Tripathi. 2018. Effect of Secondary Treated Distillery Spentwash on Physiological and Quality Parameters of Bt Cotton-II. Int.J.Curr.Microbiol.App.Sci. 7(12): 874-879.

doi: https://doi.org/10.20546/ijcmas.2018.712.109 